\title{
O DEBATE TEÓRICO SOBRE MUDANÇA DE REGIME POLÍTICO: O CASO BRASILEIRO ${ }^{1}$
}

\author{
Carlos S. Arturi \\ Universidade Federal do Rio Grande do Sul
}

\begin{abstract}
RESUMO
A longa duração e o gradualismo da transição para o regime democrático no Brasil permitiram que esse processo fosse objeto de diferentes abordagens, constituindo assim um caso privilegiado para a verificação de hipóteses a respeito da "terceira onda" de democratizações. O objetivo central deste artigo é o de analisar a transição brasileira, a partir de 1974, relacionando-a com a forte inflexão nas perspectivas analíticas sobre mudanças de regime político verificada na última década.
\end{abstract}

PALAVRAS-CHAVE: política brasileira; autoritarismo; transição; democracia; elites; militares..

\section{INTRODUÇÃO}

O processo de transição para o regime democrático no Brasil, a partir de 1974, desenvolveuse simultaneamente a uma forte inflexão nas perspectivas analíticas sobre mudanças de regime político. As análises centradas em variáveis macroestruturais, que haviam sido predominantes até o fim da década de 1970, foram fortemente contestadas por outras perspectivas que privilegiavam fatores eminentemente políticos e institucionais no estudo das transições de regimes autoritários. A longa duração e o gradualismo da transição brasileira permitiram que esse processo fosse objeto de análise de diferentes abordagens, constituindo assim um caso privilegiado para a verificação de hipóteses a respeito dos processos de democratização recentes. Este trabalho pretende contribuir para o debate teórico sobre o tema ao apresentar os resultados da pesquisa de doutoramento do autor, que teve como objeto a estratégia de liberalização política implementada pelas presi-

1 Este trabalho foi originalmente apresentado na mesaredondaConsolidaçãoda democracia: enfoquesteónicoseprocessos político-institucionais, realizada durante o Seminário Intemacional de Ciência Política: Política desdeel Sur, entre 3 e 5 de outubro de 2001 na Universidade Federal do Rio Grande do Sul (UFRGS). O evento foi organizado como patrocínio do Departamento de Ciência Política da UFRGS, do seu Programa de Pós-Graduação emCiênciaPolítica e da Associação das Universidades do Grupo de Montevidéu. dências dos generais Ernesto Geisel (1974-79) e João Figueiredo $(1979-85)^{2}$.

O estudo da tentativa que os detentores do poder fizeram para liberalizar gradualmente e sob controle o regime autoritário e institucionalizar uma democracia "forte", na qual os militares mantivessem um direito de veto sobre a vida política do país, revelou que eles foram relativamente bemsucedidos em seus propósitos ${ }^{3}$. Com efeito, o processo de liberalização política no Brasil foi, entre

\footnotetext{
2 A teseLeBrésil: unetentativededémocratisation octroyée(19741985), defendida no Institut d'Etudes Politiques de Paris, foi publicada na França, como mesmo título, em 2000. A principal fonte de dados da pesquisa consistiu em duas dezenas de entrevistas realizadas comos principais dirigentes do regime autoritário, incluindo os depoimentos dos expresidentes Emesto Geisel e Jaão Figueiredo, ecomos líderes mais destacados da oposição no período. Ver Arturi (2000).

3 O resultado desse longo processo de liberalização política foi certamente mais democrático do que aquele pretendido pelos dirigentes autoritários quando o iniciaramemmeados da década de 1970. A eleição indireta do líder da oposição moderada, Tancredo Neves, para Presidente da República em 1985, contrariava, de fato, os planos iniciais dos dirigentes autoritários, que almejavameleger para o cargo um de seus quadros civis. A democratização política completa do país durante o govemo de José Samey (1985-1990, cujos marcos foram a proclamação da nova Constituição em 1988e as eleições diretas para a Presidência em 1989, também foi certamente mais profunda do que aquela preferida pelos autores do projeto de "abertura" política.
} 
todos os casos recentes de transição, o mais controlado pelos dirigentes autoritários e aquele em que os membros de sua elite civil garantiram não só sua sobrevivência política como ampla participação no poder após a democratização. As Forças Armadas conseguiram prerrogativas políticas extraordinárias, que as mantêm como um dos atores políticos centrais, com grande poder informal, sobretudo em momentos de crise política. Os antigos dirigentes autoritários também obtiveram a garantia de que não haveria "revanchismo" contra os agentes do Estado que cometeram crimes no exercício da repressão contra a oposição, outro problema candente para a consolidação dos novos regimes democráticos instaurados nas duas últimas décadas.

A pesquisa da tese, cujos resultados este trabalho sintetiza, buscou compreender esse singular fenômeno político: como puderam os dirigentes do regime autoritário alcançar um resultado tão próximo daquele que almejaram quando iniciaram o processo de liberalização em meados da década de 1970, apesar do grande crescimento e diversificação da oposição no período, da resistência da "linha dura" à abertura política e dos importantes constrangimentos econômicos que tiveram que enfrentar?

A resposta a essa questão implica também uma contribuição ao conhecimento teórico e ao debate científico sobre processos de transição de regimes políticos, objeto deste artigo. Com efeito, a produção acadêmica a respeito dos processos de transição política defronta-se com uma série de problemas, originados por insuficiente investigação empírica e dificuldades metodológicas derivadas da ausência de uma teoria geral das mudanças políticas (NOHLEN \& THIBAUT, 1994). Nesse sentido, a "terceira onda" de democratizações (HUNTINGTON, 1991) provocou tanto uma inflexão importante nas teorias sobre transições políticas como uma série de generalizações sobre o tema, que devem ser testadas e afinadas por estudos de caso, como faremos neste trabalho a partir da experiência brasileira.

A hipótese principal do trabalho foi a de que os principais constrangimentos à consolidação do regime democrático no Brasil devem-se ao sucesso da estratégia de liberalização do regime autoritário implementada com alto grau de voluntarismo e controle do processo político pelas presidências Geisel e Figueiredo. Isso, não obstante as dificuldades encontradas pelo General Figueiredo para conduzir o processo político e sua sucessão nos últimos anos de seu governo, devido às pressões e à mobilização crescente da oposição e de amplos setores sociais que exigiam a democratização efetiva e imediata do país. Como hipótese complementar, consideramos que a longa duração e a evolução extremamente gradual da fase de liberalização política, assim como a utilização da competição eleitoral como recurso institucional privilegiado da transição, criaram no mundo político brasileiro uma percepção de "normalização" do processo conduzido sob o controle e segundo as regras impostas unilateralmente pelos detentores do poder. Essas regras foram como que "naturalizadas" nas avaliações, cálculos e elaboração de estratégias pelos principais atores políticos ao longo do período 4 . Esse fator "tempo" revelou-se fundamental para o alargamento progressivo do setor moderado da oposição e daquele reformista do regime. Nesse sentido, a perda de controle sobre a transição, ao final da presidência Figueiredo, significou a autonomização da lógica do processo $^{5}$, originado por uma estratégia voluntarista dos dirigentes do regime e modelado pelas características mais tradicionais da vida política brasileira: uma "práxis autoritária associada a uma lógica liberal" (TRINDADE, 1985), a centralidade política dos militares e a tradição de conciliação "pelo alto" das elites políticas.

\section{ODEBATE TEÓRICO SOBRE TRANSIÇÕES PARA O REGIME DEMOCRÁTICO}

Uma definição do regime democrático, mesmo que restrita à sua dimensão exclusivamente político-institucional, exige a observância das seguintes condições: 1) que todos os atores políticos relevantes devem submeter-se à livre com-

\footnotetext{
${ }^{4}$ Essa hipótese baseia-se em dois artigos de Bolívar Lamounier sobre a importância das eleições na transição brasileira. Ver Lamounier (1985; 1988, p. 110, 194).

5 Esse argumento foi desenvolvido originalmente por Renato Lessa, a partir da análise dos resultados das eleições de 1982 sobre os rumos da transição (LESSA, 1989, p. 90103). Por sua vez, Lamounier (1988, p. 111), considera que a autonomização da transição no Brasil ocomeu após a vitória daoposição nas eleições de 1974 Preferimos, diferentemente, considerar esse processo "autonomizado" apenas a partir do momento em que nenhumdos atores possuaconcretamente a capacidade de alterar suas regras. No caso emanálise, como aponta Lessa, isso ocomeu após as eleições de 1982, quando políticos da oposição forameleitos govemadores nos estados mais importantes do país.
} 
petição pacífica pelo poder, seja por valorizarem a democracia, seja por cálculo político que indique que os custos e riscos de não a aceitar são maiores do que seguir suas regras 6 ; 2) que nenhum ator político possua poder de veto quer sobre a participação de outros, quer sobre os resultados da competição política; 3) que não existam instituições estatais independentes e autônomas frente ao poder político democraticamente eleito. Uma definição "minimalista" do regime democrático, como essa, está longe de obter unanimidade na literatura, mas a definição da democracia como regime político, cuja base fundamental é a livre competição pacífica pelo poder e a garantia das liberdades civis fundamentais, possui grande capacidade operatória no domínio da pesquisa. No caso deste trabalho, a definição político-institucional é suficientemente pertinente, pois ela contempla a mesma dimensão do tema da pesquisa, qual seja, a mudança de regime político.

Os principais enfoques e orientações temáticas no estudo das transições foram modificando-se à medida que tentavam capturar as rápidas transformações nos processos em curso (NOHLEN \& THIBAUT, 1994, p. 15). Assim, sob influência da "história real", isto é, do início das "transições pactuadas" no Sul da Europa e na América Latina, os analistas - muitos deles atuantes como atores políticos naqueles processos - passaram a privilegiar as variáveis tipicamente políticas, como a qualidade das lideranças, as escolhas racionais e os recursos dos atores, bem como os efeitos da interação de suas estratégias na configuração das transições para o regime democrático. Essa mudança de perspectiva, a partir da década de 1980, ocorreu em detrimento das explicações "macro-orientadas", que privilegiavam a influência das variáveis econômicas e sociais - nível de desenvolvimento econômico, estrutura de classes, fases de industrialização - no processo de mudança política $^{7}$. A radical reorientação analítica deve-se,

\footnotetext{
6 Segundo vários autores, essa condição assume expressões diferentes. Assim, para Linz, a democracia deve ser considerada paraas principais forças políticas como "theonly gameon town"; já para Przeworski elaseriaconsiderada "um mal menor", e, para Whitehead, esse regime poderia ser o escolhido "by default" de outros viáveis (cf. MOISÉS, 1995).

7 Para uma revisão crítica da produção acadêmica sobre processos de transição e consolidação da democracia, ver Santiso (1993); ver tambémBanegas (1993) e Mbisés (1995).
}

em primeiro lugar, à terceira onda de democratizações a partir do início dos anos 1970, que surpreendeu a grande maioria dos cientistas políticos e forneceu uma inegável contraprova empírica às teorias que apontavam macrovariáveis de ordem econômica (grau de desenvolvimento econômico), social (modernização) ou cultural (cultura cívica) como pré-condições para a existência de democracias ${ }^{8}$. Efetivamente, como assinala Banegas, "essas abordagens macrohistóricas foram criticadas por seu viés determinista, às vezes finalista $\mathrm{e}$, sobretudo, por sua tendência a confundir correlações estatísticas com causalidade histórica" (BANEGAS, 1993). No prefácio à edição brasileira de Polyarchy de Dahl, Fernando Limongi fez uma apreciação sintética e acurada da influência dos processos de democratização recentes na teoria das mudanças políticas: "A constituição deste objeto de pesquisa a transição de regime - foi concomitante à afirmação da autonomia explicativa de variáveis propriamente políticas. Dito de outra maneira, essa literatura foi um dos veículos por meio dos quais a ciência política liberou-se da teoria da modernização e de suas explicações calcadas no processo histórico de transformação das estruturas sociais" (LIMONGI, 1997, p. 12). A participação de muitos intelectuais como atores políticos certamente influenciou essa perspectiva de análise centrada na escolha e na ação política - afinal, "um bom prático precisa desse tipo de ilusão heróica para agir"9.

O enfoque "micropolítico" parte do pressuposto de que a transição de um regime autoritário à democracia é um processo que depende predominantemente de variáveis que se referem à intervenção e ao voluntarismo dos atores políticos que participam da transição. Segundo essa perspectiva, nas "conjunturas fluidas" (DOBRY, 1986) de transição, quando a incerteza relativa às regras e à continuidade do jogo político é a característica central, os condicionamentos do processo político normalmente determinados pela estrutura econômica e social encontram-se como que "suspensos" (KARL \& SCHMITTER, 1991). Ao siste-

\footnotetext{
8 Uma análise crítica dessas teorias encontra-se em Hermet (1986) e em Heper (1991).

9 Expressão utilizada por Michel Dobry emum seminário sob responsabilidade de Guy Hermet no Institut d'Etudes Politiques de Paris, em 16fev. 1994.
} 
matizarem a abordagem "micropolítica", O’Donnell e Schmitter preconizam que as análises a respeito das transições dos regimes autoritários devem orientar-se por uma "teoria da 'anormalidade', na qual o inesperado e o possível são tão importantes quanto o comum e o provável. [...] [Pois] a 'metodologia da ciência normal' não é apropriada em situações de rápida mudança, cujos parâmetros da ação política encontram-se em movimento" (1988, p. 18-19). Assim, ganham relevo decisivo na determinação desses processos, para esses autores, a atuação e a habilidade das elites políticas e de suas lideranças (a virtù dos atores) e os eventos inesperados (a fortuna). Do ponto de vista metodológico, a investigação política orientou-se para o individualismo metodológico, a teoria das escolhas racionais e a interação estratégica.

Assim, muitos autores procuraram construir modelos explicativos das transições de regime baseados na identificação de atores centrais, na formalização de seus objetivos, na distribuição de suas preferências. Essas abordagens muitas vezes incorrem em formalização e simplificação excessivas, misturam níveis de análise, desprezam a história política e institucional do país estudado, negligenciam os dados contextuais da transição e, sobretudo, superavaliam a racionalidade dos atores, muitos deles em processo de constituição ao longo daquelas conjunturas (BANEGAS, 1993). Alguns autores, como Di Palma, exacerbam o papel do voluntarismo político na construção da democracia e desconsideram praticamente outras variáveis que não se refiram diretamente aos atores políticos e ao contexto das transições (DI PALMA, 1990). Essa postura ensejou, em muitas autores, a formulação de "receituários" prescritivos e normativos destinados a orientar o comportamento dos atores políticos e a construção de instituições supostamente mais adequadas para levar a bom termo os processos de transição e a consolidação da democracia. O conjunto de prescrições (guidelines) elaborado por Huntington para os atores políticos democráticos e o intenso debate acadêmico sobre a forma de governo mais adequada para consolidar as novas democracias na América Latina, presidencialismo ou parlamentarismo, são exemplares dessa tendência normativa, inspiradas por tentativas de "engenharia política" ${ }^{10}$. No que concerne à identi-

$\overline{10}$ O processo de transição no Brasil foi, antes mesmo de seu ficação de seus interesses e à formação de suas escolhas, há que se ter presente o fato de que a racionalidade dos atores é limitada, sobretudo nos processos de transição, nos quais as regras do jogo político estão em constante modificação. Ademais, os atores políticos e os indivíduos não agem exclusivamente em função apenas dos seus interesses, identificados racionalmente, mas também são guiados por ideologias, valores e por motivações "simbólicas". Nesse sentido, a legitimação constitui um fator muito importante para a estabilidade dos regimes democráticos e um sério obstáculo para o exercício do poder autoritário. A observação de Przeworski de que a ausência de legitimidade não é suficiente para provocar per se a crise de um regime autoritário, se não estiver associada a existência de uma alternativa de poder viável, é de fato pertinente, contudo nenhum regime se estabiliza sem esse atributo de valor à ordem política. Linz foi pioneiro em apontar o déficit de legitimidade dos regimes autoritários, ao estudar o caso brasileiro no início dos anos 1970, como um sério empecilho para sua institucionalização, num momento em que outros autores previam essa possibilidade baseados em análises macro-orientadas ${ }^{11}$. Por sua vez, a instalação de regimes democráticos na maioria dos países latino-americanos, a partir da década de 80 , coincidiu com a maior crise econômica e com a reforma radical do modelo de desenvolvimento econômico orientado pelo Estado. A sobrevivência da democracia nessas condições adversas sugere fortemente que o apoio de caráter normativo da população a esse regime é portanto mais forte que a crise econômica e social na região (REMMER, 1992-1993, p. 5). Por sua vez, onde o regime democrático foi derrubado, como foi o caso do Peru, isso ocorreu por outras razões, como lembram Nohlen e Thibaut (1994).

início, o centro de especulações desse tipo. Emmeados de 1972 Huntington formulou, a convite do Ministro-Chefe daCasa Civil do govemo Médici, Leitão de Abreu, umroteiro de reformas políticas para liberalizar o regime autoritário, que naquele momento encontrava-se no ápice da repressão política. As sugestões que formulou, talvez a primeira tentativa de "engenharia política" explícita conhecida, só foram aproveitadas dois anos mais tarde, pelo General Golbery do Couto e Silva, o principal estrategista político do govemo Geisel.

11 Ver a revisão crítica desse debate emLamounier (1988). 
O maior risco das análises centradas em escolhas e ações dos atores consiste na racionalização retrospectiva e na tendência finalista das tentativas de reconstrução do passado (LINZ \& STEPAN, 1995). Os atores políticos agem, na realidade, quase sempre imersos na incerteza sobre o contexto de suas ações e sobre o efeito e reações que elas produzirão nos outros atores, sobretudo nos processos de transição nos quais não podem contar com as referências políticas habituais e estáveis. A análise não pode portanto subestimar o sentimento de risco e as dificuldades em que eles incorrem quando agem em "conjunturas fluidas". A tendência dos pesquisadores, e dos próprios atores individuais envolvidos no jogo político, é todavia reconstruir a motivação das ações e a lógica dos acontecimentos a partir do seu resultado final. $\mathrm{O}$ analista político deve portanto procurar compreender a avaliação, as escolhas e a ação dos atores como eles a viveram no momento de sua realização. Apesar das referidas limitações e das precauções que devem ser consideradas quando se adota a perspectiva micropolítica, essa abordagem provocou um efeito muito salutar na literatura especializada, ao ressaltar o risco da reificação no estudo dos processo políticos, isto é, o Estado, as Forças Armadas, as classes sociais e os atores serem considerados "como um só homem" na determinação de seus interesses e na sua atuação política.

As insuficiências das abordagens "macroestruturais" e da "micropolítica" levou Terry Karl a propor um enfoque mediano, que nos parece bem mais promissor para a compreensão dos processos de transição à democracia. A autora elaborou a noção de "contingência" para escapar do dilema "determinismo das estruturas versus liberdade do ator" e capturar os vínculos entre os fatores macroestruturais, a tradição institucional do país e a opções dos atores políticos. É preciso demonstrar "como, em dado momento, o leque de opções disponíveis é função das estruturas criadas em período anterior e como essas decisões estão condicionadas pelas instituições estabelecidas no passado" (KARL, 1991, p. 423). Nessa perspectiva, as instituições políticas pré-existentes realizam a mediação entre a estrutura sócioeconômica e as ações dos atores políticos, pois elas fornecem os parâmetros do espaço político e os recursos institucionais disponíveis para a ação dos atores (BADIE \& HERMET, 1990). Por exemplo, no caso brasileiro, a condução do projeto liberalização política através do processo eleitoral não foi propriamente uma "escolha" do governo Geisel, como se este o tivesse implementado para este fim com clareza dos objetivos a atingir. $\mathrm{Na}$ realidade, sua utilização deu-se basicamente pelo fato de que um sistema partidário e um calendário eleitoral estarem disponíveis e em funcionamento. A existência de eleições e a sobrevivência de instituições políticas liberais, mesmo durante o período mais ditatorial do regime autoritário, devese a uma característica tradicional do sistema político brasileiro, desde a independência do país, qual seja, a competição intraelites pelo poder político através de eleições. Todavia, as opções e as ações dos atores "devem ser interpretadas não só em função de oportunidades e constrangimentos pré-existentes, mas também em relação as que nascem da própria transição" (BANEGAS, 1993).

Em suma, a interação entre a estrutura econômica, social e política pré-existente e a estratégia dos atores políticos permite arranjos institucionais e comportamentais que condicionam as possibilidades de uma consolidação democrática. Nesse sentido, ganham importância as escolhas e decisões realizadas anteriormente para o resultado dos processo de transição, por menor que seja sua significação no momento em que foram tomadas, pois elas podem incidir de maneira decisiva nas etapas posteriores da democratização, facilitando ou não o êxito desses processos. Por exemplo, os acordos entre os militares e a oposição, estabelecidos na fase de liberalização política, podem persistir longamente, originando uma democracia com "defeitos de nascença" (KARL \& SCHMITTER, 1991, p. 286). Dessa maneira, traços da cultura política de um país, comportamentos historicamente arraigados e constrangimentos estruturais podem, ou não, ser reforçados pelas escolhas e ação dos atores políticos em uma determinada conjuntura. A persistência da conjuntura de crise econômica e a adoção de planos de estabilização econômica, muitas vezes sem discussão prévia com a sociedade e com o Congresso, agravam aspectos centrais das "democracias delegativas" da região (O'DONNELL, 1994). Esse conceito refere-se aos regimes da "terceira onda" de democratizações que são, segundo O'Donnell, "intrinsecamente hostis aos padrões de representação normais das democracias estabelecidas, à criação e consolidação das instituições políticas e, especialmente, à 'prestação 
de contas horizontais' [accountability]" (O'DONNELL, 1993, p. 165). Esses regimes democráticos não-institucionalizados caracterizam-se pela delegação aos governantes eleitos da possibilidade de realizarem tudo que lhes pareça adequado para minorarem a crise econômica aguda ${ }^{12}$. Os elementos plebiscitário e personalista das "democracias delegativas" teriam suas origens no estilo populista e na baixa institucionalização que marcaram o passado político da região.

Ainda no que concerne ao peso das variáveis na explicação dos fenômenos de transição dos regimes autoritários, a preponderância dos fatores políticos e institucionais não deve, entretanto, subestimar a influência das variáveis macroestruturais nesses processos. De fato, como constataram Linz e Stepan (1996), aqueles regimes autoritários que permitiram um pluralismo político limitado, assim como a existência de arenas sociais e econômicas relativamente livres do controle do Estado e extensivas, favoreceram a transição para a democracia e constituíram elementos positivos para sua eventual consolidação. Quanto às microvariáveis políticas que possuem relação com o regime anterior, esses autores destacam duas centradas em atores: a liderança do antigo regime e "quem inicia e quem controla a transição". A questão aqui é se a transição foi uma iniciativa do regime ou da oposição, e se esse processo foi controlado pelos dirigentes autoritários ou por um governo interino após o colapso do antigo regime. Linz e Stepan mantêm o foco da análise nos atores e nas lideranças políticas, mas incorporam na explicação variáveis estruturais e históricas. Os autores querem identificar quais traços provenientes da formação do Estado-nação - práticas e instituições - e paths de processos de transição (por exemplo, "pactuadas" ou via colapso) facilitam ou dificultam a consolidação da democracia.

\section{O REGIME AUTORITÁRIO E O INÍCIO DA TRANSIÇÃO}

Um processo de democratização totalmente finalizado envolve genericamente três etapas: o

\footnotetext{
12 No Brasil, os planos Cruzado, em 1986, e Collor, em 1990 foramexemplares desse tipo de delegação plebiscitána por parte da população, que de fato apoiou a posteriori uma série de profundas medidas econômicas implantadas de maneira autoritária.
}

início da dissolução do regime autoritário, a criação da democracia e a consolidação do novo regime (BERMEO, 1992, p. 273). A longa e gradual transição no Brasil permite distinguir com clareza esses períodos. O primeira vai de março de 1974 a março de 1985, e abrange os dois últimos governos militares, as presidências dos generais Geisel (1974-1979) e Figueiredo (1979-1985). A segunda etapa - a construção da democracia desenvolve-se durante o governo civil de José Sarney (1985-1990). Quanto ao processo de consolidação do novo regime democrático, uma espécie de segunda transição, ela inicia-se com a presidência de Fernando Collor de Mello em março de 1990 (eleito por sufrágio universal e afastado do poder por um processo de impeachment em dezembro de 1992), e encontra-se ainda em andamento. No que diz respeito a este trabalho, é imperativo desenvolver uma análise mais acurada da primeira etapa, que corresponde ao período coberto pela pesquisa. Alguns estudiosos dos processos de democratização recentes na América Latina destacam uma forte afinidade entre tipos de regimes autoritários precedentes, modos de transição à democracia e dilemas decorrentes das características desses processos para a consolidação dos novos regimes democráticos (NOHLEN \& THIBAUT, 1994). Essa relação, no entanto, não é tão imediata como parece à primeira vista; nesse sentido, uma análise sucinta da significativa mudança política que ocorreu no Brasil nas últimas décadas possibilitará uma avaliação empírica das teses mais correntes sobre os processos de democratização e permitirá também afinar nossas hipóteses iniciais.

Uma particularidade importante a ser ressaltada que diferencia a autocracia brasileira de regimes similares na região foi o fato de apresentar a mais longa duração dentre todos, de ser o mais bem sucedido do ponto de vista econômico, o menos repressivo entre seus congêneres e aquele no qual "os militares como corporação, e não um militar, assumiram a responsabilidade pelo poder e adaptaram as instituições políticas à nova ordem autoritária" (SOARES, 1994, p. 13). De fato, seus dirigentes sempre consideraram o autoritarismo como formato político transitório e mantiveram, praticamente durante todo o período, a existência de partidos políticos, um calendário eleitoral e o Congresso em funcionamento, embora com restrições políticas importantes, como veremos adiante. Essa ambigüidade institucional da ditadura 
no Brasil revela-se extremamente importante para a análise, pois as características do regime autoritário precedente podem ser, de fato, consideradas como uma macrovariável política fundamental para a determinação do modo de transição e do tipo de democracia que resultará. O processo de democratização brasileiro apresenta também como uma de suas características centrais o fato de ter se desenvolvido através de negociações sob forte controle dos dirigentes autoritários. Sob esse aspecto, ele é similar ao caso espanhol, como ressaltam Share e Mainwaring (1988). No entanto, uma diferença notável entre os dois países foi a dominância militar no regime autoritário brasileiro e na iniciativa de liberalizá-lo, ao passo que na Espanha o regime franquista era bem menos militarizado e a transição foi conduzida pelas lideranças civis; essa distinção entre os dois casos ajuda a compreender a centralidade do problema do controle do poder político democrático sobre as Forças Armadas como fundamental para a consolidação da democracia no Brasil (AGUERO, 1992). Outra discrepância marcante entre os dois países foi a rapidez do processo espanhol e a renovação de suas elites políticas, em contraste com a longa duração, o extremo gradualismo e o enorme grau de continuidade das lideranças do antigo e do novo regime democrático brasileiro, que problematizam sobremaneira sua consolidação (LESSA, 1989). Esse fato demonstra por si só os limites das generalizações das teorias de transição ${ }^{13}$.

III.1 A liberação do regime autoritário: voluntarismo e controle sob a Presidência Geisel (1974-1979)

Uma das teses mais difundidas na literatura especializada, defendida por O'Donnell, argumenta que os regimes autoritários nos quais a repressão foi menos brutal e que conheceram períodos de crescimento econômico significativo, seus dirigentes possuem recursos políticos que lhes permitem tomar a iniciativa de "abrir" o regime e negociar com a oposição a passagem do poder, resguardando algumas de suas prerrogativas e sua sobrevivência política. Assim, quanto maior o apoio político com que conta o regime autoritário no

\footnotetext{
13 Ver uma crítica sobre o alcance explicativo das teorias sobre transição de regime, baseadas em perspectivas comparativas, emHermet (2001).
}

início da transição, mais gradual e controlado seria esse processo e, portanto, maiores seriam as dificuldades de consolidação da democracia, em virtude da presença de "resíduos autoritários" no novo regime (O'DONNELL, 1988). Com efeito, quando o governo Geisel deu início à liberalização política em 1974, os militares já haviam consolidado o modelo de modernização conservadora cujo lema "segurança e desenvolvimento" resumia suas características. As altas taxas de crescimento do então "milagre econômico" e a dizimação da contestação armada fornecem apoio social e recursos políticos e econômicos consideráveis ao novo governo, permitindo-lhe ousar uma estratégia de transição política que ainda não encontrava apoio majoritário no seio da elite dirigente.

O início da liberalização política acontece quando os dirigentes de um regime declaram a intenção de promover sua liberalização e são acreditados pelos principais atores políticos. No caso brasileiro, este momento ocorreu no final de 1974, quando o governo Geisel aceitou a ampla e inesperada vitória do partido da oposição (MDB) nas eleições de novembro desse ano, para deputados das Assembléias dos estados, para a Câmara dos deputados federais e para o Senado. Com efeito, a promessa de Geisel de iniciar uma "distensão política lenta, gradual e segura", formulada poucos dias após sua posse em março anterior, encontrou muito ceticismo da parte da oposição e da sociedade, pois todos os presidentes militares anteriores haviam também prometido restaurar o regime democrático assim que assumiram o poder. Todavia, para as eleições municipais de 1976, o regime restringiu fortemente a propaganda eleitoral através de modificações da legislação específica. Em abril de 1977, o governo fechou o Congresso por poucos dias para promulgar uma série de medidas constitucionais que alteravam profundamente a legislação eleitoral e constrangiam a oposição democrática, no intuito de garantir a maioria do Congresso para o partido do governo (ARENA) nas eleições de 1978, assim como no Colégio Eleitoral encarregado de escolher o próximo presidente da República no início de 1979, além de adiar para 1982 as eleições diretas para governadores dos estados, entre outras medidas arbitrárias. Geisel conseguiu, assim, controlar firmemente o processo de liberalização, ao golpear alternadamente a oposição, com reformas pragmáticas visando a manter maioria governista no Congresso, e a "linha dura" militar, 
sobretudo quando demitiu o Ministro do Exército, no final de 1977, que almejava sucedê-lo. A partir desse episódio, todos os atores políticos envolvidos na transição perceberam que havia uma segurança relativamente alta na continuidade do processo. Outro fator de importância capital para sua aceitação foi a hegemonia dos setores liberais e conservadores no interior das forças de oposição. $\mathrm{O}$ fato mais significativo do alinhamento das esquerdas em geral às regras da transição negociada impostas pelo regime foi o seu apoio efetivo à candidatura do General Euler Bentes Monteiro, pelo MDB, contra o candidato do regime, General Figueiredo, no Colégio Eleitoral no final de 1978. Nessa mesma época, Geisel extinguiu o principal instrumento jurídico e o símbolo maior da ditadura militar, o Ato Institucional n. 5, que lhe permitia alterar unilateralmente as regras do jogo político. A transição passou a ter, então, uma dinâmica própria, no sentido de que as primeiras medidas liberalizantes outorgadas constituíram-se em novas regras do jogo político, tornando quase impossível um recuo institucional, sob pena de desmoralizar os partidários do projeto de liberalização e minar sua "legalidade autoritária" (SANTOS, 1988).

Em suma, durante a presidência do General Geisel (1974-1979), o processo político foi dominado pelo governo e restrito, de fato, às forças conservadoras e à oposição parlamentar aglutinadas, respectivamente, na ARENA e no MDB - conforme previa o projeto de "distensão". Durante a presidência Geisel, a existência de um apoio político significativo ao regime, a fragilidade da oposição frente aos recursos coercitivos do governo e a virtù dos dirigentes autoritários permitiram que estes últimos fossem muito bemsucedidos na implantação e no controle de seu projeto de democratização outorgada. Geisel legou a seu sucessor, por ele escolhido, General João Figueiredo, a tarefa de aprofundar a liberalização do regime e, como parte de sua estratégia de transição, passar o poder ao término de seu mandato, em 1985, a um político civil proveniente do partido do regime. Os caprichos da fortuna realizaram essa tarefa por vias tortas, pois, com a morte de Tancredo Neves, assumiu o poder José Sarney, que havia sido um dos quadros civis mais proeminentes do regime autoritário. Assim, apesar do governo Figueiredo ter perdido o controle do processo político nos últimos anos de seu governo, o resultado final da fase de liberalização política foi muito próximo daquilo havia sido projetado pelos mentores da transição "lenta, gradual e segura".

\section{III.2 A autonomização da transição durante a Presidência Figueiredo (1979-1985)}

O General Figueiredo assumiu a Presidência da República em março de 1979 apregoando a democracia como objetivo final da "abertura política" que promoveria durante seu governo. Entretanto, a ausência da principal legislação autoritária (AI-5), abolida meses antes de sua posse, a recessão econômica e o surgimento de movimentos sociais, como o "novo sindicalismo", aceleraram fortemente o processo político, tornando a tentativa de sua condução pelo governo cada vez mais problemática. Apesar desses constrangimentos, o governo Figueiredo prosseguiu com a estratégia gradual das reformas políticas. No final de 1979, o regime propôs e fez aprovar pelo Congresso uma anistia ampla e politicamente inteligente, pois seu alcance concernia tanto aos prisioneiros e exilados de esquerda como, preventivamente, a todos aqueles indivíduos ligados aos órgãos de segurança do regime que cometeram crimes durante as atividades repressivas. Todavia, o surgimento de um vigoroso movimento sindical, que teve seu marco inicial nas grandes greves dos operários metalúrgicos paulistas no final da década de setenta, foi fundamental para acelerar a "abertura política" do governo Figueiredo e constituiu uma novidade no sistema eleitoral brasileiro. De fato, o "novo sindicalismo" introduziu um ator político estranho ao conjunto das forças conservadoras e liberais que, até então, eram os únicos protagonistas da transição.

No que concerne à utilização do processo eleitoral para pautar a transição, esse recurso praticamente se esgotou com a última reforma institucional do regime autoritário: a extinção dos dois partidos existentes (ARENA e MDB) e a implementação do multipartidarismo, em 1979. A anistia e a reforma partidária se inscreviam na estratégia do regime de dividir a oposição para acabar com o caráter plebiscitário crescentemente desfavorável ao regime, das eleições bipartidárias. Esta manobra foi parcialmente vitoriosa, pois a oposição dividiu-se, com efeito, entre vários partidos e os quadros do regime permaneceram majoritariamente no novo partido governista, o PDS (Partido Democrático Social). A oposição, 
por sua vez, percebeu que diminuíam as possibilidades de profundas alterações na ordem institucional e acomodou-se às regras vigentes, com a atenção voltada para as eleições de 1982 para governadores de estado, a serem realizadas pela primeira vez desde 1966. A estratégia das diversas correntes oposicionistas orientou-se, desde então, para a consolidação dos novos partidos e para a disputa eleitoral, colocando em um plano secundário outras questões políticas que não se referissem aos temas exclusivamente partidários e eleitorais, como a convocação de uma Assembléia Constituinte, por exemplo. A divisão da oposição em vários partidos antes mesmo do final do regime autoritário facilitou a reacomodação das elites políticas, permitindo que a transição "pactuada" se realizasse exclusivamente em termos institucionais, sem pactos explícitos e substantivos entre os atores políticos, como no caso espanhol. Essa característica foi responsável pela sobrecarga da agenda política no período posterior, principalmente durante os trabalhos da Assembléia Nacional Constituinte (LESSA, 1989).

O ano de 1981 foi fundamental para o processo de transição no Brasil. De fato, a explosão de uma bomba no interior de um automóvel ocupado por militares, no estacionamento do Riocentro em 31 de abril, teve conseqüências múltiplas e importantes para o futuro político do país. Em primeiro lugar, o episódio significou o fim dos atentados perpetrados pela extrema-direita inconformada com o processo de transição, que ocorriam desde o final de 1979. Isso forneceu a todos os atores políticos a certeza de que o processo de transição não mais corria o risco de ser interrompido por um golpe proveniente dos setores "duros" do regime. O segundo efeito importante do caso Riocentro foi a demissão do General Golbery do Couto e Silva de seu cargo de Ministro-Chefe da Casa Civil, que ocupava desde o início da presidência Geisel, já que ele exigia a apuração completa dos fatos e a punição dos responsáveis pelos atentados. A substituição do estrategista-mor da "abertura política" pelo ex-Ministro do governo Médici, Leitão de Abreu, um homem público respeitado no interior dos círculo dirigente do regime, mas que não era afeito às manobras político-parlamentares, constituiu uma ruptura com o projeto estratégico do General Golbery. Logo após assumir, Leitão de Abreu fez aprovar pelo Congresso, no final de 1981, um "pacote" eleitoral que proibia as coligações partidárias, impunha o voto vinculado a um mesmo partido para todos os cargos eletivos, sob pena de sua anulação, entre outras medidas. O Pacote de Novembro, como ficou conhecido, inviabilizou a sobrevivência do Partido Popular, de Tancredo Neves e de outras lideranças conservadoras da oposição democrática. Ora, a manutenção do PP como eventual força auxiliar do partido do regime, o PDS, para eleger no Colégio Eleitoral em janeiro de 1985 um quadro civil do regime fazia parte dos planos de Golbery. As medidas adotadas por Leitão de Abreu forçaram a reincorporação do PP ao PMDB no início de 1982 e enrijeceram o quadro partidário, ocasionando o retorno do caráter plebiscitário, pró ou contra o regime, que as eleições expressavam desde 1974. Nesse caso, ficou mais uma vez estabelecida a importância da qualidade das lideranças políticas na condução de um processo de transição (ARTURI, 2000, cap. 5).

Os resultados das eleições para Governador de estado e para deputados estaduais e federais em 1982 deram uma vitória política expressiva às oposições e foram diretamente responsáveis pela perda do controle do processo de transição pelo regime. Graças aos senadores escolhidos indiretamente em 1978, o partido governamental manteve ainda a maioria no Congresso e no Colégio Eleitoral que se reuniu em janeiro de 1985 para eleger o Presidente da República seguinte. Mas, a partir da eleição de 1982, quando os partidos de oposição conquistaram dez governos estaduais entre os mais importantes do país e a maioria das cadeiras na Câmara dos Deputados, o governo teve que administrar o país negociando diretamente com poderosos governadores da oposição e fazer face ao crescente desgaste político. Essa situação marcou o retorno de uma das características mais duradouras do sistema político nacional: o poder dos governadores de estado e a centralidade da política regional na formação de alianças no Congresso (ABRUCIO \& SAMUELS, 1997). A oposição partidária e a sociedade civil organizada começaram, assim, a tolher gradativamente a margem de manobra do regime e a inverter o domínio político da transição, sempre na estrita observância da legislação política-eleitoral imposta pelos governos militares. Esse quadro político complexo, somado ao sentimento de segurança da oposição quanto à irreversibilidade da transição, notadamente após a neutralização da extremadireita militar devido ao caso Riocentro em 1981, provocaram uma multiplicação de estratégias 
visando à sucessão presidencial, com um objetivo político igual ao do governo: eleger o futuro Presidente no Colégio Eleitoral em janeiro de 1985.

Foi nesse contexto que surgiu a surpreendente mobilização pelas eleições diretas à Presidência da República em 1984, conhecida como movimento "Diretas-Já". Ela foi a reivindicação mais forte e concreta pela democratização do país após 1964 e pôs em cheque, momentaneamente, a estratégia política do regime e os planos das lideranças oposicionistas mais conservadoras, que já negociavam possíveis alianças com setores do partido governista. O movimento pelas eleições diretas para Presidente da República mobilizou milhões de pessoas por todo o país, mas não conseguiu impedir a rejeição, em abril de 1984, do projeto de emenda constitucional que a implantaria. Entretanto, esse movimento foi fundamental para estimular e justificar o apoio da dissidência do regime, a Frente Liberal, ao candidato do PMDB à presidência, Tancredo Neves. A grande campanha pelas "Diretas-Já", e sua impotência para alterar as regras impostas pelo regime autoritário, foi paradigmática da liberalização "pelo alto" através de acordos e cisões no seio das elites políticas no Congresso; pois, se por um lado ela facilitou a dissidência governista e impediu um hipotético recuo políticoinstitucional, por outra lado ela foi incapaz de dar um desfecho verdadeiramente democrático ao processo de transição, pelo simples fato de que a maioria das lideranças oposicionistas e do próprio governo estavam, naquela conjuntura, satisfeitos com a "legalidade autoritária" e com os ganhos políticos vislumbrados. Os eventos posteriores são bem conhecidos: a eleição da chapa Tancredo Neves e José Sarney em janeiro de 1985; a internação hospitalar de Tancredo gravemente doente na véspera de sua posse em 15 de março; sua morte em 21 de abril. Assim, a fortuna e as opções dos príncipes tornaram José Sarney, o expresidente do PDS e líder das forças governistas na derrubada da emenda pelas eleições diretas meses antes, o primeiro Presidente civil desde 1964.

O pacto político, que certamente ocorreu, entre o candidato oposicionista e os militares, para impedir qualquer turbulência política na reta final da liberalização, garantindo àqueles últimos prerrogativas e salvaguardas políticas, foi facilitado pelo gradualismo e pela longa duração do processo, o que permitiu o transformismo político de muitos atores. Assim, nos últimos anos do governo
Figueiredo, praticamente já não mais existiam nem os radicais da oposição, nem a "linha-dura" do regime, os quais os moderados de ambos os lados deveriam teoricamente isolar para levar a bom termo a transição. O continuísmo e o excesso de "garantismo" tornaram-se as marcas da democratização outorgada brasileira, cujo êxito devese à combinação entre a estratégia voluntarista do regime autoritário e o auto-enquadramento da maioria da oposição na lógica e nas regras impostas pelo regime autoritário. A lentidão, o gradualismo e o controle exercido nesse período pelos detentores do poder legaram "resíduos autoritários" e reforçaram práticas políticas tradicionais do país que problematizaram fortemente a fase seguinte de democratização, sob o governo Sarney, e constrangeram o processo de consolidação do novo regime democrático a partir de 1990.

\section{O REGIME DEMOCRÁTICO E OS FATO- RES DE SUA CONSOLIDAÇÃO}

O deslocamento do interesse das pesquisas da fase inicial da transição para a problemática da consolidação da democracia acelerou-se quando a instauração desse tipo de regime revelou-se mais auspiciosa do que inicialmente previsto pelos especialistas. Nesse momento, emergiu uma crítica aos limites da democracia política e/ou às chances de sua consolidação na ausência de profundas reformas econômicas e sociais. Esses questionamentos centram-se quer nas limitações propriamente políticas do regime democrático "delegativas", cidadania de baixa intensidade (O’DONNELL, 1993), "low democracy" (GILL \& ROCAMORA, 1992), "liberalismo democrático" (NUN, 1994) - quer definindo a democracia através de variáveis socialmente substantivas, isto é, como um tipo de sociedade específica ("democracia social", "democracia popular" etc.). Ora, a consideração de variáveis sociais, econômicas e culturais (alto grau de desigualdade social, crise econômica, cultura política autoritária, transformação do papel do Estado, ofensiva ideológica neoliberal etc.) é pertinente, sobretudo, para a identificação dos dilemas e constrangimentos à consolidação da nova ordem política. Com efeito, a consolidação da democracia é uma espécie de segunda transição e a avaliação da estabilização e enraizamento desse regime em um determinado país requer um considerável recuo temporal. A consolidação da democracia, como afirma Morlino, "não se trata de um processo inovador. Ao contrário, é caracte- 
rizado pelo estabelecimento sólido de estruturas e procedimentos que pretendem durar. [...] A fase de transição é bastante distinta da de consolidação. Trata-se, basicamente, da diferença entre fluidez e estabelecimento sólido" (MORLINO, 1992, p. 152-153).

Fundamentalmente, a consolidação da democracia exige que a incerteza em relação à competição pelo poder torne-se aceitável para os principais atores políticos; em outras palavras, que eles concordem que os vencedores de eleições, independentemente de quem sejam, assumam o poder que estava em disputa, e os derrotados não tentem um recuo político-institucional para alterar, a posteriori, as regras do jogo. A importante contribuição de Przeworski para a identificação desse elemento central das regras do jogo democrático deve contudo ser relativizado. De fato, a incerteza quanto aos resultados da competição política só é aceitável para os antigos dirigentes do regime autoritário e para as classes dominantes se vier acompanhada de outras "certezas" que restrinjam o alcance de eventuais reformas econômicas, sociais e políticas que possam ser implementadas por qualquer das forças políticas que venham a vencer a disputa pacífica pelo poder (PRZEWORSKI, 1984). É necessário, portanto, distinguir a incerteza típica das transições, relativa à possibilidade de recuos do processo e às regras do jogo em constante fluxo, da incerteza limitada quanto aos resultados da disputa eleitoral que caracteriza uma democracia consolidada. Assim, a incerteza é um elemento central das transições, mas não do regime democrático, como argumenta Mainwaring (1992). Nessa perspectiva, toda transição bem-sucedida para a democracia seria basicamente conservadora, pois implica acordos e pactos, quer sejam públicos quer sejam implícitos, que garantam a propriedade privada, assegurem os dirigentes autoritários e os militares de que eles não serão perseguidos no novo regime democrático e, como no caso brasileiro, terão garantida sua sobrevivência política (PRZEWORSKI, 1992). Todavia, esses elementos que favorecem a transição - moderação e objetivos minimalistas por parte da oposição, oportunismo e controle por parte dos reformistas do regime e facilitam o bom termo do processo revelam-se, posteriormente, obstáculos e constrangimentos para a consolidação da democracia. Como salienta Przeworski, a estratégia ótima para as transições "pactuadas" é contraditória: "as forças que pro- movem a democracia precisam ser prudentes $e x$ ante e desejam ser resolutas ex post. Mas as decisões tomadas anteriormente criam condições que são difíceis de reverter depois, pois elas preservam o poder das forças associadas ao regime autoritário" (PRZEWORSKI, 1994, p. 111). Em suma, a exigência do abandono daquelas instituições e arranjos que facilitaram a transição, mas que são consideradas antidemocráticas e que podem acarretar uma "morte lenta" da democracia, é pouco viável.

Houve também alterações significativas na hierarquização do valor explicativo das variáveis segundo a fase do processo de democratização. $\mathrm{O}$ foco temático das pesquisas deslocou-se das condições de emergência das transições - crise dos regimes autoritários, causas da liberalização política, alianças e conflitos entre atores - para os dilemas relativos à consolidação da democracia prerrogativas militares, construção de instituições democráticas, reforma do Estado sob conjunturas de grave crise econômica etc. Durante a transição propriamente dita do regime autoritário à democracia, as variáveis mais influentes seriam aquelas concernentes à qualidade da ação dos atores políticos e à interação de suas estratégias. Inversamente, após a instauração do regime democrático, as variáveis macrossociais (nível de desigualdade social, tipo de política econômica, influência de fatores internacionais, grau de reforma do Estado etc.) e institucionais (sistema de governo, sistema eleitoral-partidário etc.) constituiriam os fatores mais importantes para o sucesso ou fracasso da consolidação do novo regime.

Essas mudanças bruscas de enfoque refletem a ausência de modelos explicativos a partir da sequiência regime autoritário-modo de transiçãotipo de democracia. Nesse sentido, Nohlen e Thibault afirmam que os maiores problemas para a consolidação do regime democrático não se originam da crise econômica ou das contradições entre pactos de elite e demandas sociais por reformas, mas de mecanismos institucionais, tais como a relação entre Executivo e Legislativo ou a perda de capacidade de agregação e representação dos sistemas políticos (NOHLEN \& THIBAUT, 1994, p. 26). Por sua vez, Przeworski (1992) destaca que o repertório de arranjos institucionais para construir a nova ordem política é bastante limitado e os atores refugiam-se, frequientemente, nas práticas e instituições tradicionais para con- 
figurar o novo regime. De fato, na opinião de Share e Mainwaring a maneira pela qual a democracia é instalada não determina totalmente seu desenvolvimento posterior, mas estabelece as regras do jogo, as modalidades de interação e os limites ao comportamento dos atores e às mudanças políticas; em suma, o mais importante seriam as condições iniciais do regime democrático (SHARE \& MAINWARING, 1988). Isso posto, em nosso entender, os dilemas enfrentados pelo regime democrático constituem-se em obstáculos políticos que ou originaram-se do modo de transição do regime autoritário (path dependency) ou são características tradicionais do sistema político brasileiro que foram reforçados pelo processo de transição gradual e controlado.

\section{A NOVA REPÚBLICA (1985-1990) E OS DILEMAS PARA CONSOLIDAÇÃO DO REGIME DEMOCRÁTICO}

A fase de democratização no Brasil desenvolveuse durante a presidência civil de José Sarney (19851990), intitulada "Nova República", quando foi levantada a proibição dos partidos comunistas e deuse a expansão máxima do sufrágio com a permissão ao voto dos analfabetos, em 1985. Posteriormente, verificou-se a redação e aprovação da nova Constituição democrática em 1988, e ocorreu a realização de eleições diretas para Presidente da República em 1989, pela primeira vez desde 1961. Com a posse do vencedor dessas eleições em dois turnos, Fernando Collor de Mello, em março de 1990, teve início o regime democrático propriamente dito. Durante a presidência Sarney, os constrangimentos postos à construção e consolidação do novo regime foram múltiplos e interdependentes: persistência da crise econômica com forte crescimento da inflação, fragilidade política da "Aliança Democrática", falta de legitimidade do Presidente Sarney aos olhos da maioria da população e presença de importantes resíduos autoritários oriundos da transição "pelo alto". O conjunto desses obstáculos relacionou-se estreitamente com a transição "através de eleições" durante os dois últimos governos militares e com a dinâmica do sistema partidário e eleitoral na Nova República. Com efeito, a ausência de pactos públicos durante a fase de liberalização política provocou, com a morte de Tancredo, uma situação de transição "à refaire" 14 , que agravou as dificuldades políticas

${ }^{14}$ Esta expressão foi utilizada por Philippe Schmitter em do presidente Sarney. A aceitação da eleição de Tancredo pelos militares foi baseada, quase que exclusivamente, na sua "confiabilidade" política pessoal, que garantiria tanto o cumprimento das prerrogativas políticas oferecidas às Forças Armadas, como as promessas de que os interesses econômicos fundamentais das classes dominantes não seriam atingidos por eventuais reformas. Sarney herdou ainda um ministério que era fruto de acordos políticos realizados por Tancredo com vários setores isoladamente, e cujo teor era praticamente ignorado pelo novo Presidente. Enfraquecido por essa situação e pela tentativa do PMDB e de seu Presidente, Deputado Ulysses Guimarães, de dirigir a administração do país e orientar as reformas políticas, o Presidente da República reagiu apoiando-se politicamente nos militares e utilizou-se fartamente de práticas clientelistas para aliciar individualmente parlamentares de vários partidos, bem como articulou alianças com governadores de estado para que influenciassem suas bancadas federais. Ambos os estratagemas enfraqueceram os partidos políticos e o Congresso, e só foram exeqüíveis porque essas instituições já se encontravam fragilizadas em decorrência do modo de transição e de seus efeitos sobre a legislação eleitoral, os partidos e as práticas políticas.

A orientação conservadora impressa pela Presidência da República encontrou nas características e práticas tradicionais do sistema partidário brasileiro um instrumento privilegiado para sua efetivação. Nesse sentido, Sarney utilizou-se do apoio dos governadores para isolar a ala mais progressista do PMDB, recompor o perfil de sua administração e obter o apoio parlamentar necessário para governar. Ele administrou o país com uma forte presença dos membros mais conservadores da Aliança Democrática e de outros partidos, a maioria dos quais provenientes da Frente Liberal, a dissidência de undécima hora do regime autoritário. A maioria liberal-conservadora no Congresso em 1985, que incluía os senadores "biônicos" designados pelo regime em 1978, a vontade da presidência da República e as pressões dos militares impuseram uma Assembléia Constituinte formada pelos membros da Câmara dos

uma conferência ministrado no Institut des Hautes Études de l'Amérique Latine (IHEAL), emParis, no dia 8de março de 1993 
deputados e do Senado que seriam eleitos em 1986, derrotando assim a proposta da esquerda que almejava uma Assembléia composta de representantes eleitos exclusivamente para redigir a nova Carta. Estas mesmas forças pressionaram com êxito a Assembléia Constituinte a limitar o alcance das reformas econômicas e sociais, sobretudo no que diz respeito à Reforma agrária, fixar em cinco anos o mandato presidencial de José Sarney e a adotar o sistema presidencialista de governo. No que concerne especificamente ao sistema partidário-eleitoral, a Constituinte congressual foi responsável, primeiro, pela manutenção da super-representação dos estados do norte e nordeste do país e a sub-representação daqueles do sul e sudeste na Câmara dos deputados. Em segundo lugar, a redação da nova Constituição pelo Congresso ocorreu sob grande influência dos governadores sobre as bancadas federais de seus estados, o que reforçou a tradicional articulação da política nacional via acordos regionais, em detrimento das relações interpartidárias e do fortalecimento interno dos partidos políticos. Finalmente, a Constituinte congressual foi em parte responsável por cisões partidárias que deram origem a novos partidos - como é o caso do PSDB, que surgiu a partir de uma dissidência do PMDB. Em suma, reproduziu-se um traço característico do sistema partidário brasileiro que sempre o fragilizou, qual seja, a da que os partidos quase sempre surgem de cisões intraelites nos períodos de mudanças de regimes (LIMA JR., 1993).

A sobrecarga da agenda econômica e social da Constituinte - em razão da ausência de pactos substantivos entre os atores sociais no período anterior de liberalização política - e as pressões corporativas de quase todos os setores organizados do país produziram, por sua vez, a indefinição de muitos dos princípios políticos e econômicos contemplados pela nova Carta, que foram remetidos para a regulamentação posterior através de leis ordinárias. A ambigüidade do PMDB e de seu Presidente Ulysses Guimarães - que era também, simultaneamente, Presidente da Câmara de Deputados e da Assembléia Constituinte -, dilacerados entre assumir a condição de partido no poder e a condição de herdeiro da oposição ao autoritarismo, constituiu um fator importante para o descrédito das forças democráticas que lideraram o processo de transição. Nesse sentido, a eleição presidencial por sufrágio universal de 1989 possui múltiplas significações. No que concerne ao tema deste trabalho, a campanha e os resultados da eleição em dois turnos marcaram o início efetivo do regime democrático no país e o final do longo processo de transição política que começara 15 anos antes. Essa eleição também apontou alguns constrangimentos importantes sobre o sistema partidário, provocados pelo modo de transição, sobretudo inquietantes indícios de deslegitimação dos partidos políticos e o baixo grau de identificação partidária do eleitorado. Efetivamente, os candidatos dos dois maiores partidos em 1989, PMDB e PFL - que juntos detinham mais da metade do número de cadeiras do Congresso -, Ulysses Guimarães e Aureliano Chaves, não ultrapassaram, respectivamente, $4 \%$ e $2 \%$ dos votos no primeiro turno da eleição. Ora, esses candidatos eram os líderes da Aliança Democrática, que possibilitou a eleição de Tancredo no Colégio Eleitoral em 1985 e a instauração do primeiro governo civil após 1964. Por sua vez, os dois candidatos mais votados e que disputaram o segundo turno da eleição foram Fernando Collor de Mello (25\% dos votos), do inexpressivo PRN, que detinha apenas 21 cadeiras na Câmara em 1989, e Luiz Inácio "Lula" da Silva, do PT. Ambos os candidatos representavam a oposição e a rejeição da maioria da população aos políticos tradicionais e ao governo ${ }^{15}$. O processo de impeachment de Collor e a posse de Itamar Franco em dezembro de $1992^{16}$, que ocorreram rigorosamente dentro dos preceitos constitucionais, constituem indubitavelmente um signo de vitalidade do regime democrático. Esses eventos não afastam, todavia, os indícios de uma ordem política ainda precária, na qual o sistema partidário apresenta-se como um dos elementos mais frágeis.

A revalorização dos fatores institucionais na análise dos processos de transição e consolidação da democracia aponta, no caso brasileiro, para duas características importantes da tradição política do país, que se revelaram centrais na configuração do processo de transição e para os constrangimentos do atual regime democrático: a tutela dos militares sobre o sistema político, con-

\footnotetext{
15 Leonel Brizola, que ficou em terceiro lugar no primeiro tumo, com $136 \%$ dos votos, tambémencamava a oposição à Nova República e foi candidato por um partido relativamente pequeno (PDT).

16 Paraumaanálise mais detalhada das múltiplas implicações políticas doimpeachment, verMbnclaire (1994).
} 
solidada após 1964, e a utilização da competição eleitoral, mesmo que limitada, para regrar os conflitos entre as elites políticas. Com efeito, segundo Rouquié, os países que sofreram um longo período de autoritarismo sob direção dos militares, como no caso do Brasil, devem satisfazer ainda duas condições políticas indispensáveis à consolidação da democracia: 1) o efetivo controle civil sobre os militares, e 2) a real possibilidade de alternância das forças políticas no poder (ROUQUIÉ, 1986). Ora, no caso brasileiro, a primeira dessas pré-condições ainda não se verificou e a segunda ainda não foi verdadeiramente testada. Por um lado, as atuais prerrogativas constitucionais e o poder informal dos militares brasileiros são extremamente amplos, o que lhes acarreta um alto grau de autonomia em relação ao aparelho de Estado (MORAES, 1987; STEPAN, 1991; OLIVEIRA, 1994; ZAVERUCHA, 1994; SOARES, D'ARAÚJO \& CASTRO, 1995). Essa situação configura-se como praticamente incompatível com um regime democrático (ZAVERUCHA, 2000). Os acordos da oposição com os militares, que permitiram a passagem do poder sem maiores riscos, foram de fato centrados numa série de garantias quanto à não-punição dos crimes cometidos pelos órgãos de segurança do antigo regime e a manutenção de prerrogativas das Forças Armadas que lhes permitiram ampla autonomia em relação às instituições políticas e influência sobre o processo de constituição da nova ordem democrática. A tutela militar sobre o sistema político vigorou durante o governo Sarney ${ }^{17}$, quando os ministros militares, sobretudo o do Exército, pressionaram fortemente o Presidente e o Congresso constituinte no sentido de restringir as reformas sociais e políticas exigidas por setores do PMDB, que detinha mais da metade dos ministérios, e da oposição de esquerda. A grande influência das Forças Armadas nesse período decorreu da baixa legitimidade do Presidente Sarney aos olhos da opinião pública e, em parti-

\footnotetext{
17 Zaverucha (1994) qualificou a ascendência militar sobre a presidência Samey de tutela "amistosa". Emsua obra mais recente, Frágil democracia (2000), esse autor, ao analisar a atuação política dos militares nos govemos democráticos de Fernando Collor, Itamar Franco e Fernando Henrique Cardoso, reafimaque "háaindaumlongo e tortuoso caminho a percomer numo à democratização das relações civil-militares no Brasil. O ponto de não-retomo ao autoritarismo ainda não foi atingido pela frágil democracia brasileira" (p. 313).
}

cular, dos líderes do PMDB, que não se conformavam em submeter-se politicamente a um Presidente que há muito pouco tempo saíra do interior do regime autoritário. Além de seu passado como quadro importante do antigo regime, a fragilidade política do Presidente era agravada pela frustração da população com o fracasso da campanha pelas eleições diretas e pela morte inesperada de Tancredo Neves; Sarney era assim considerado como um "usurpador" pela maior parte da população. Segundo Eliézer de Oliveira, Sarney aproximou-se do "aparelho militar que, ao apoiar o presidente, indica-lhe também diversos limites para as políticas de governo" (OLIVEIRA, 1994, p. 111). O aspecto mais visível da atuação política dos militares foi a forte pressão que exerceram sobre a Assembléia Constituinte, no sentido de impor a forma de governo presidencialista, a duração de cinco anos para o mandato do Presidente Sarney, a limitação da anistia aos militares de esquerda punidos ao longo do regime autoritário, e o veto a reformas sociais que poderiam provocar conflitos graves, em particular a reforma agrária. Há autores que acreditam que os militares no Brasil perderam muito do poder político que detinham no momento da posse do Presidente Sarney em 1985. Wendy Hunter (1997), em um trabalho recente, sustenta que a razão dessa erosão do poder e das prerrogativas políticas dos militares durante os governos Sarney, Collor e Itamar Franco foi o desenvolvimento de uma dinâmica política eleitoral típica dos regimes democráticos no período. Esse processo, associado ao fim da Guerra Fria e à falência da esquerda radical, teria provocado um esforço dos políticos para reduzir tanto o orçamento como as esferas de influência dos militares, transferindo recursos econômicos e de poder para a arena partidário-eleitoral ${ }^{18}$. Essa pesquisa pode ser questionada, em primeiro lugar, pela evidência empírica

\footnotetext{
18 Hunter defende a tese de que, no Brasil, "a dinâmica competitiva da democratização produz imesistúveis incentivos para os políticos civis contestarem a influência militar", o que seria responsável pela atenuação do poder e das prerrogativas políticas das Forças Armadas após a 1985 (1997, p. 6). A autora contudo reconhece que os militares permanecem como fator de poder no cálculo dos atores, sobretudo em crises, e naquelas ocasiões em que falta apoio popular ao Presidente da República. Cremos, assim, que Hunter identificou excessivamente o afastamento das Forças Armadas do centro de decisões políticas como erosão significativa e duradoura da influência política militar (idem, p. 144).
} 
relativa a "tutela" que os militares brasileiros efetivamente exerceram ao longo do governo Sarney. Em segundo lugar, Zaverucha demonstra que o controle civil democrático sobre os militares não existe ainda no Brasil, onde as Forças Armadas continuam detendo largas prerrogativas e considerável autonomia política até os dias de hoje, e alerta que a dimensão militar na transição e na consolidação democrática tem sido subestimada pelos analistas políticos (ZAVERUCHA, 2000) ${ }^{19}$.

Ainda no que concerne às dúvidas quanto à consolidação do regime democrático, a derrota do candidato das forças de esquerda nas eleições presidenciais de 1989 impediu que a transição brasileira vivesse sua verdadeira prova de fogo, isto é, a eventual transferência do poder das forças que até então o detinham para aquelas que representavam os seus adversários históricos. Essa condição é importante no caso brasileiro, assim como no argentino, pois nesses dois países a passagem de poder sempre foi problemática. O retorno sistemático do tema de uma eventual adoção do regime parlamentarista de governo no país, bem como a tramitação sem percalços de um projeto parlamentar nesse sentido, constitui um indício de que parte das elites políticas não admite, de fato, a alternância no poder na presidência da República, salvo se este for diminuído.

Quanto aos constrangimentos à consolidação da democracia oriundos do processo de transição recente, destaca-se o alto grau de continuidade entre as elites do regime autoritário e do novo regime. Esses traços marcantes da democratização no Brasil devem-se aos acordos e coalizões entre as lideranças moderadas da oposição e reformistas do antigo regime, realizados basicamente no interior do Congresso, através da divisão de cargos e recursos políticos entre esses atores no novo governo civil iniciado em 1985. Essas condições foram responsáveis, ao lado de outros fatores que examinaremos adiante, pela fragilidade das novas

\footnotetext{
19 Outros autores têmuma opinião mais nuançada que Zaveruchaa respeito do poder dos militares após a transição, pois, embora reconheçamque as Forças Ammadas mantiveram premogativas daépoca dos regime autoritário e muito poder informal, destacam os avanços democratizantes que ocomeramnas relações civil-militares nos últimos anos, como a criação do Ministério da Defesa, e tambémo despreparo e o descaso das elites civis em relação aos assuntos militarese de defesa. Ver Oliveira (2000) e D’Araújo e Castro (2001).
}

instituições políticas democráticas, sobretudo do sistema partidário. Com efeito, Hagopian (1992) destaca a grande migração de lideranças políticas do regime autoritário para a oposição durante seus dois últimos anos de existência (1983-1985). Segundo a autora, esse "transformismo" foi induzido pelas lideranças oposicionistas e, efetivamente, facilitou a transição ao propiciar o surgimento de uma dissidência organizada (Frente Liberal) no seio do partido do governo na época para formar com o maior partido da oposição (PMDB) uma aliança política. A chamada Aliança Democrática apresentou as candidaturas de Tancredo Neves (PMDB) para Presidente da República e de José Sarney (PFL) para vice junto ao Colégio Eleitoral encarregado de escolher a nova presidência em janeiro de 1985. A morte de Tancredo Neves foi responsável pela maior vicissitude que sofreu um processo de transição na América Latina: a ascensão à Presidência da República daquele que fôra Presidente do partido do regime autoritário até poucos meses antes.

Assim, tanto os militares como as elites civis conservadoras que haviam sofrido um forte desgaste político e eleitoral, a partir de meados da década de 1970, mantiveram boa parte de suas posições no interior do Estado após o afastamento dos militares do poder em março de 1985. Como a eleição de Tancredo Neves e José Sarney realizou-se num Colégio Eleitoral no qual a maioria de seus membros pertencia ao partido governista, a oposição e seus aliados "dissidentes" tiveram que negociar os votos, em boa parte através de arranjos clientelísticos que produziram um elevado continuísmo político. Posteriormente, as forças conservadoras civis aumentaram mais ainda sua presença no Congresso ao trocarem de etiqueta partidária, favorecidas por uma grande liberalidade da legislação partidário-eleitoral no que concerne à formação de novos partidos e à livre troca de legendas dos parlamentares. O alto grau de continuísmo das elites autoritárias na Nova República pode ser ilustrado pelo fato de que, por ocasião das eleições gerais de 1986, que formou a Assembléia Constituinte, foram eleitos 217 deputados que pertenciam ao antigo partido de apoio ao regime autoritário (ARENA) e apenas 212 provenientes da antiga oposição democrática (MDB) durante o período do bipartidarismo imposto (1966-1979). Esse resultado também deve-se ao prestígio e apoio significativos de que ainda desfrutavam o regime autoritário e suas lideranças na 
época, em virtude do desenvolvimento econômico alcançado e das posições de poder que mantiveram após seu término. Aliás, a presença no poder da elite política civil do regime autoritário após a instauração da democracia é maior atualmente do que no governo Sarney. De fato, o PFL, a partir de 1990, passou a ser o principal partido de sustentação dos governos Collor e Itamar Franco e, em 1994, formou com o PSDB (Partido da Social Democracia Brasileira), a aliança que elegeu o atual Presidente Fernando Henrique Cardoso e, como vice-Presidente, Marco Maciel (PFL), ex-Senador e ex-líder do governo Geisel na Câmara dos Deputados. Em suma, os reformistas do regime autoritário foram os herdeiros políticos privilegiados do processo de transição.

A institucionalização do sistema partidário é fundamental para a consolidação do regime democrático ${ }^{20}$. A incipiente institucionalização do sistema partidário brasileiro contrasta com a grande importância que os partidos políticos e as eleições exerceram na democratização do regime autoritário. O sistema partidário é a instituição que sofre maior influência dos pactos realizados entre as elites políticas, como afirma Hagopian, pois se as pressões dos movimentos sociais e populares constrangem o regime autoritário e podem ser decisivos na instauração da democracia, eles entretanto não elaboram o desenho institucional do novo regime. Em relação aos fatores concernentes à fragilidade do sistema partidário que deitam suas raízes na história política do país, destacam-se a estreita dependência dos partidos em relação ao Estado e a centralidade da política regional na formação de alianças partidárias e eleitorais, características que, segundo Campello de Souza (1988), possuem maior valor explicativo que o propalado "continuísmo" conservador. Nessa perspectiva, um dos constrangimentos mais duráveis à democracia oriundos do golpe de 1964 foi, justamente, a interrupção do sistema partidário do período 19451966, que demonstrava uma tendência de forte identificação eleitoral. A influência do regime

\footnotetext{
20 "Um sistema partidário institucionalizado implica a estabilidade da competição entre os partidos, a existência de organizações fortemente enraizadas na sociedade, o reconhecimento dessas organizações partidánias e das eleições como instituições legítimas na escolha dos govemantes e a vigência de partidos que comportam regras e estruturas estáveis" (MAINWARING \& SCULY, 1994, p. 44).
}

autoritário reforçou, assim, um traço secular no sistema político brasileiro, caracterizado pela combinação de uma "lógica liberal" com uma "práxis autoritária" (TRINDADE, 1985), e que é, em parte, responsável por uma cultura política que resiste à democratização da esfera pública e à expansão da cidadania. $\mathrm{O}$ regime autoritário, ao perseguir o controle do processo político, produziu três sistemas partidários distintos em seus vinte $\mathrm{e}$ um anos de existência. $\mathrm{O}$ grande intervencionismo estatal e a fraca institucionalização do sistema político provocaram a erradicação completa da identificação partidária anterior ao golpe de 1964, caso único entre todos os processos de transição ocorridos na América Latina.

Uma série de outros fatores problematizam igualmente a atual ordem política e constituem constrangimentos importantes à consolidação da democracia. Em relação aos obstáculos provocados por fatores econômicos e sociais, a enorme desigualdade de renda e a ausência de reformas sociais prometidas pela antiga oposição ao autoritarismo fazem que a maioria da população associe a ineficácia das sucessivas políticas governamentais à vigência do regime democrático. Essas variáveis macroestruturais incidem no processo político constrangendo a consolidação da democracia de diversas maneiras. A grande concentração da renda no Brasil provoca indiretamente graves efeitos políticos, tais como o encolhimento da comunidade política, a dificuldade de manutenção da ordem pública, a falta de confiança nos políticos - fatores que minam a legitimidade do regime democrático a longo prazo (REIS \& CHEIBUB, 1993). Com efeito, o Estado não consegue exercer o monopólio da violência e impor a ordem política no conjunto do território nacional, onde subsistem por exemplo trabalho escravo e justiça privada, sobretudo nas áreas rurais. Por sua vez, as agências estatais resistem em atender com eqüidade e reconhecer os direitos da população mais pobre e das minorias sociais; especialmente os órgãos de segurança pública, que persistem no emprego de métodos arbitrários e violentos sobre esses setores. No caso brasileiro, esse padrão de atuação, desrespeitoso com os direitos humanos fundamentais, tem sua origem no passado escravista do país, mas foi reforçado pelo longo período autoritário. O'Donnell utiliza-se do conceito de "cidadania de baixa intensidade" para descrever a curiosa situação na qual "se respeitam os direitos participativos e democráticos da 
poliarquia, mas se viola o componente liberal da democracia. [...] Essa bifurcação constitui o reverso da moeda da complexa mescla de componentes democráticos e autoritários nesses estados" (O’DONNELL, 1993, p. 173).

\section{CONCLUSÕES}

A literatura especializada destacou a forte afinidade que existiria entre o tipo de regime anterior, o modo de transição e os constrangimentos à consolidação da democracia, como foi discutido na "Introdução" deste trabalho. As características do regime autoritário, a tradição política e o padrão institucional adotado configuram e delimitam o processo de transição. Por sua vez, embora não sejam imutáveis, os comportamentos políticos e o padrão institucional estabelecidos ou reafirmados durante esses processos são responsáveis por uma herança durável que afeta o novo regime democrático e as chances de sua consolidação (MUNCK \& LEFF, 1997). Esses efeitos do modo de transição sobre o novo regime incidem sobretudo sobre o padrão de competição e interação entre as elites e sobre as regras institucionais e os limites que são postos à mudança política, isto é, afetam as condições iniciais do novo regime democrático. No que concerne às fases do processo de transição, nos casos em que elas podem ser distinguidas, fenômeno semelhante também ocorre. Nesse sentido, a fase de liberalização do regime autoritário brasileiro desenvolvida gradualmente através de eleições e acordos não-públicos entre os principais atores legou uma série de constrangimentos políticos que dificultam a consolidação da democracia.

Este trabalho procurou demonstrar que a adoção de uma determinada via institucional para conduzir a liberalização política - a competição eleitoral limitada pela legislação autoritária -, com grande afinidade com a tradição política do país, provocou gradativamente a autonomização do processo e a "naturalização" de suas regras pelos principais atores políticos. Nessa perspectiva, o caso brasileiro confirma a hipótese da path dependency, isto é, uma vez adotado determinado padrão institucional, ele tende a estabilizar-se e a enquadrar a atividade política. A possibilidade de modificações significativas na tradição política e no padrão institucional de um país dar-se-ia em certas "conjunturas críticas", como é o caso dos processos de transição de regime (HUNTER,
1997). Ora, a investigação empírica da liberalização do regime autoritário no Brasil permite qualificar melhor essa proposição, ao demonstrar que naqueles processos de transição que se realizam de maneira muito gradual e controlada, as mudanças de regime político podem ocorrer sem alterações importantes no padrão institucional e nas práticas políticas tradicionais. No caso em análise, a única possibilidade, em mais de uma década de liberalização política, que poderia ter resultado numa ruptura institucional com o antigo regime no início de 1984 quando se desenvolveu a grande campanha por eleições diretas para Presidente da República - foi abortada porque os principais atores políticos já estavam satisfeitos com "legalidade autoritária". Assim, a opção dos atores mais relevantes nesse período reforçou a tradição brasileira de conciliação "pelo alto" das elites políticas, a utilização da competição eleitoral para mensurar o poder dos dirigentes face a seus opositores (contra-elites) e a presença dos militares como um dos atores centrais no sistema político.

A aceitação e a incorporação nas estratégias dos atores políticos, inclusive da maior parte das forças da oposição, das regras impostas pelo regime foi também facilitada porque a abertura política posta em marcha pelos dirigentes autoritários adquiriu gradualmente uma dinâmica própria que gerou a autonomização desse processo em relação a seus autores, já em meados da presidência Figueiredo. De fato, a extinção da legislação mais arbitrária (AI-5) em 1978, a anistia e o retorno ao sistema multipartidário no ano seguinte, a neutralização da extrema-direita militar em 1981 por ocasião do caso Riocentro, as eleições diretas para governadores de estado em 1982, surtiram efeitos cada vez mais democráticos e dificilmente reversíveis, sob pena de um recuo definitivo do processo de transição. A oposição moderada, sob a liderança de Tancredo Neves, construiu sua estratégia de alcançar a presidência da República tendo em vista as regras autoritárias em vigor, e aproveitou os efeitos perversos produzidos pela estratégia de liberação imposta pelos detentores do poder. A tentativa de "democratização outorgada" escapou ao controle destes últimos e o desenvolvimento do processo autonomizou-se (LESSA, 1989), estruturando o jogo político, o qual nem os dirigentes do regime nem a oposição poderiam unilateralmente alterar, a menos que houvesse uma ruptura institucional, hipótese já altamente improvável. Assim, quando 
surgiu a possibilidade de uma saída verdadeiramente democrática, que significaria uma verdadeira ruptura com o regime autoritário (a campanha "Diretas-Já"), os líderes moderados da oposição não a julgaram conveniente, pelos riscos que implicava de um veto militar, mas também porque contrariava seus objetivos estratégicos, que era obter a Presidência da República no Colégio Eleitoral segundo a legislação em vigor.

Concluindo, cremos que ficou comprovado que o modo de transição exerce grande influência no resultado dos processos de transição e na configuração dos constrangimentos para a consolidação do novo regime democrático. No caso estudado, a perda de controle dos dirigentes autoritários sobre sua tentativa voluntarista de democratização outorgada não provocou um resultado muito diferente daquele que almejaram. De fato, a autonomização da transição, ao invés de provocar uma ruptura institucional com o antigo regime, enquadrou esse processo no padrão institucional tradicional do país, reforçando suas características que tornam o sistema político brasileiro resistente tanto à ditaduras clássicas quanto à sua democratização estável (LAMOUNIER, 1989). Aos dilemas políticos para a consolidação da democracia que se originaram do processo de transição, devem ser acrescentados aqueles concernentes à crise econômica e à desigualdade social, bem como os decorrentes da profunda mudança no papel do Estado, pela qual passa atualmente a sociedade brasileira ${ }^{21}$. Em suma, a consolidação da democracia no país ainda é apenas uma possibilidade alvissareira.

Recebido para publicação em 8 de outubro de 2001. Artigo aprovado em 23 de novembro de 2001.

21 Ver Sallum Jr. (1996). Para uma análise da transição brasileira de uma perspectiva temporal mais dilatada, envolvendo ciclos de mobilização política e reformas institucionais, ver Rodrigues (2001).

Carlos S. Arturi (arturi@zaz.com.br) é Doutor em Ciência Política pelo Instituto de Estudos Políticos de Paris e Professor do Departamento de Ciência Política da Universidade Federal do Rio Grande do Sul (UFRGS).

\section{REFERÊNCIAS BIBLIOGRÁFICAS}

ABRUCIO, F. \& SAMUELS, D. 1997. A nova Política dos Governadores. Lua Nova, São Paulo, n. 40-41, p. 137-166.

AGUERO, F. 1992. The Military and the Limits to Democratization. In : MAINWARING, S., O'DONNELL, G. \& VALENZUELA, A. Issues in Democratic Consolidation: The New South American Democracies in Comparative Perspective. Notre Dame : University of Notre Dame Press.

ARTURI, C. S. 2000. Le Brésil : une tentative de démocratisation octroyée (1974-1985). Villeneuve d'Ascq : Presses Universitaires du Septentrion.

BADIE, B. \& HERMET, G. 1990. Politique Comparée. Paris : Presses Universitaires de France.

BANEGAS, R. 1993. Les transitions démocratiques : mobilisations collectives et fluidité politique. Cultures et conflits, Paris, n. 12, p. 105-140, hiver.
BERMEO, N. 1992. Democracy and the Lessons of Dictatorship. Comparative Politics, v. 24, n. 3, p. 273-292, April.

CAMARGO, A. \& DINIZ, E. 1989. Dilemas da consolidação democrática no Brasil. In : . Continuidade e mudança no Brasil da Nova República. São Paulo : Vértice.

D'ARAúJo, M. C. \& CASTRO, C. 2001. Militares e política na Nova República. Rio de Janeiro : Fundação Getúlio Vargas.

DI PALMA, G. 1990. To Craft Democracy : An Essay on Democratic Transition. Berkeley : University of California Press.

DOBRY, M. 1986. Sociologie des crises politiques. Paris : Presses de la Fondation Nationale des Sciences Politiques.

GILLS, B. \& ROCAMORA, J. 1993. Low Intensity Democracy. World Quarterly, London, v. 13, n. 3, p. 521-524.

HAGOPIAN，F. 1992. The Compromised 
Consolidation : The Political Class in Brazilian Transition. In : MAINWARING, S., O'DONNELL, G. \& VALENZUELA, A.Issues in Democratic Consolidation : The New South American Democracies in Comparative Perspective. Notre Dame : University of Notre Dame Press.

HEPER, M. 1991. Transitions to Democracy Reconsidered. In : RUSTOW, D. \& ERICKSON, K. Comparative Political Dynamics : Global Research Perspectives. New York : Harper Collins.

HERMET, G. 1986. Sociologie de la construction démocratique. Paris : Economica.

2001. As transições democráticas no século XX : comparação entre América Latina e Leste europeu. In : ABREU, A. A. Transição em fragmentos : desafios da democracia no final do século XX. Rio de Janeiro : Fundação Getúlio Vargas.

HUNTER, W. 1997. Eroding Military Influence in Brazil : Politicians against Soldiers. Chapel Hill and London : University of North Carolina Press.

HUNTINGTON, S. 1991. The Third Wave : Democratization in the Late Twentieth Century. Norman : University of Oklahoma Press.

KARL, T. 1991. Dilemas de la democratización en América Latina. In : SOLANO, J. L. \& HORCASITAS, J. H. Transiciones a la democracia en Europa y América Latina. México : Miguel Ángel Porrua.

KARL, T. L. \& SCHMITTER, P. 1991. Les modes de transition en Amérique Latine, en Europe du Sud et de l'Est. Revue Internationale des Sciences Sociales, Paris, n. 128, p. 285302, mai.

LAMOUNIER, B. 1985. Apontamentos sobre a questão democrática brasileira. In : ROUQUIÉ, A., LAMOUNIER, B. \& SCHWARCZ, J. (orgs.). Como renascem as democracias. São Paulo : Brasiliense.

. 1988. O Brasil autoritário revisitado : o impacto das eleições sobre a abertura. In : STEPAN, A. (org.). Democratizando o Brasil. São Paulo : Paz e Terra.

LESSA, R. 1989. Reflexões sobre a gênese de uma democracia banal. In : DINIZ, E.,
BOSCHI, R. R. \& LESSA, R. Modernizaçãoe consolidação democrática no Brasil : dilemas da Nova República. São Paulo : Vértice.

LIMA JR. 1993. Democracia e instituições no Brasil dos anos 80. São Paulo : Loyola.

LIMONGI, F. 1997. Prefácio. In : DAHL, R. Poliarquia : participação e oposição. São Paulo : Edusp.

LINZ, J. \& STEPAN, A. 1995. Problems of Democratic Transitions and Consolidation : Southern Europe, South America and PostCommunism. Baltimore : Johns Hopkins University Press.

MAINWARING, S. 1992. Transition to Democracy and Democratic Consolidation : Theorical and Comparative Issues. In : MAINWARING, S., O'DONNELL, G. \& VALENZUELA, A. Issues in Democratic Consolidation : The New South American Democracies in Comparative Perspective. Notre Dame : University of Notre Dame Press.

MAINWARING, S. \& SCULLY, T. R. 1994. A institucionalização dos sistemas partidários na América Latina. Dados, Rio de Janeiro, v. 37, n. 1, p. 43-79.

MOISÉS, J. A. 1995. Os brasileiros e a democracia. São Paulo : Ática.

MONCLAIRE, S. 1994. Le quasi-impeachment du Président Collor. Revue Française de Science Politique, Paris, v. 44, n. 1, p. 23-47, fév.

MORAES, J. Q. 1987. O argumento da força. In : OLIVEIRA, E. R. (org.). As Forças Armadas no Brasil. Rio de Janeiro : Espaço e Tempo.

MORLINO, L. 1992. Consolidações democráticas na Europa Meridional. Indicações teóricas para análise empírica. Dados, Rio de Janeiro, v. 35 , n. 2, p. 145-172.

NOHLEN, D. \& THIBAUT, B. 1994. Investigación sobre la transición em América Latina : enfoques, conceptos, tesis. Arbeitspapier, n. 11, Universidade de Heidelberg.

NUN, J. 1994. La democracia y la modernización : treinta años después. In : SIERRA, G. Democracia emergente en América del Sur. Ciudad del México : UNAM. 
O'DONNELL, G. 1988. Transições, continuidades e alguns paradoxos. In : REIS, F. W. \& O'DONNELL, G. A democracia no Brasil : dilemas e perspectivas. São Paulo : Vértice.

1993. Acerca del Estado, la democratización y algunos problemas conceptuales. Una perspectiva latinoamericana com referencias a países poscomunistas. Desarollo Económico, Buenos Aires, v. 33, n. 130, p. 163-184, jul.sept.

1994. Delegative Democracy. Journal of Democracy, Baltimore, v. 5, n. 1, p. 55-69, Jan.

O'DONNELL, G. \& SCHMITTER, P. 1988. Transições do regime autoritário : primeiras conclusões. São Paulo : Vértice.

OLIVEIRA, E. R. 1994. De Geisel a Collor: Forças Armadas, transição e democracia. Campinas : Papirus.

OLIVEIRA, E. R. \& CORREA, S. 2000. Forças Armadas, direção política e formato institucional. In : D'ARAUJO, M. C. \& CASTRO, C. Democracia e Forças Armadas no Cone Sul. Rio de Janeiro : Fundação Getúlio Vargas.

PRZEWORSKI, A. 1984. Ama a incerteza e serás democrático. Novos Estudos CEBRAP, São Paulo, n. 9, p. 36-46.

. 1992. The Games of Transition. In : MAINWARING, S., O'DONNELL, G. \& VALENZUELA, A. Issues in Democratic Consolidation: The New South American Democracies in Comparative Perspective. Notre Dame : University of Notre Dame Press.

1994. Democracia e mercado : reformas políticas e econômicas no Leste Europeu e na América Latina. Rio de Janeiro : RelumeDumará.

REIS, E. P. \& CHEIBUB, J. B. 1993. Pobreza, desigualdade e consolidação democrática. Dados, Rio de Janeiro, v. 36, n. 2, p. 233-260.

REMMER, K. 1992-1993. The Process of Democratization in Latin America. Studies in Comparative International Development, Washington, v. 27, n. 4, p. 3-24, Winter.

RODRIGUES, A. T. 2001. O Brasil de Fernando a Fernando : neoliberalismo, corrupção e protesto na política brasileira. Ijuí : Unijuí.
ROUQUIÉ, A. 1986. Demilitarization and Military-Domineted Polities in Latin America. In : O'DONNELL, G., SCHMITTER, P. \& WHITEHEAD, L. Transitions from Authoritarian Rule. Comparative Perspectives. Baltimore : The Johns Hopkins University Press.

SALLUM JR., B. 1996. Labirintos. Dos generais à Nova República. São Paulo : Hucitec.

SANTISO, J. 1993. La démocratie incertaine. La théorie des choix rationnels et la démocratisation en Amérique latine. Revue Française de Science Politique, Paris, v. 43, n. 6, p. 970993, déc.

SANTOS, W. G. 1988. El siglo de Michels : competencia oligopólica, lógica autoritaria y transición en America Latina. In : CAVAROZZI, M. \& GARRETON, M. A. Muerte y resurreción. Los partidos políticos en el autoritarismo y las transiciones en el Cono Sur. Chile : FLACSO.

SHARE, D. \& MAINWARING, S. 1988. Transições através da negociação : a democratização no Brasil e na Espanha. In : SELCHER, W. A. (org.). A abertura política no Brasil. São Paulo : Convívio.

SOARES, G. A. D. 1994. O golpe de 64. In : SOARES, G. A. D. \& D'ARAÚJO, M. C. (orgs.). 21 anos de regime militar: balanços e perspectivas. Rio de Janeiro : Fundação Getúlio Vargas.

SOARES, G. A. D., D'ARAÚJO, M. C. \& CASTRO, C. 1995. A volta aos quartéis : a memória militar sobre a abertura. Rio de Janeiro : Relume-Dumará.

SOUZA, M. C. C. 1998. A Nova República brasileira : sob a espada de Dâmocles. In : STEPAN, A. (org.). Democratizando o Brasil. Rio de Janeiro : Paz e Terra.

STEPAN, A. 1988. As prerrogativas militares nos regimes pós-autoritários : Brasil, Argentina, Uruguai e Espanha. In : . (org.). Democratizando o Brasil. Rio de Janeiro : Paz e Terra.

.1991. Os militares : da Abertura à Nova República. Rio de Janeiro : Paz e Terra.

TRINDADE, H. 1985. Bases da democracia brasileira : lógica liberal e práxis autoritária. In : 
ROUQUIÉ, A., LAMOUNIER, B. \& SCHWARCZ, J. (orgs.). Como renascem as democracias. São Paulo : Brasiliense.

ZAVERUCHA, J. 1994. Rumor de sabres. São
Paulo : Ática.

2000. Frágil democracia. Collor, Itamar, FHC e os militares (1990-1998). Rio de Janeiro: CivilizaçãoBrasileira. 